\title{
Chapter 7 \\ Understanding Provincial and Territorial Academic Integrity Policies for Elementary and Secondary Education in Canada
}

\section{Brenda M. Stoesz (D)}

\begin{abstract}
Research on academic integrity and misconduct in higher education is not difficult to locate, as work in this area has increased dramatically over the past several decades. Overall, findings reveal that cheating is a serious problem plaguing higher education with many institutions documenting various approaches to address the relevant issues. A careful look at this literature, however, exposes significant gaps in our understanding of academic integrity and misconduct in Canadian elementary and secondary (or K-12) education, which is problematic as behaviours practiced in these settings during the formative years may influence behaviours in later life stages. Furthermore, school policies, which reinforce expectations for students and teachers in the workplace are of particular importance as K-12 teachers arguably impact students' approaches to academic integrity. This chapter focuses on key questions related to K-12 education in Canada: Do provincial and territorial ministries of education address academic integrity through policy for K-12 education? If these policies exist, what evidence demonstrates their influence on the implementation of academic integrity education at the school level? To begin to examine these questions, I conducted an environmental scan of Canadian ministries of education websites to identify academic integrity and misconduct policies. I found that only a few education ministries outline student expectations for academic integrity and consequences for misconduct or describe teacher responsibilities for providing academic integrity education and responding to academic misconduct (i.e., Newfoundland and Labrador, Manitoba, and Saskatchewan). To conclude this chapter, I discuss the implications of the presence or absence of effective academic integrity and misconduct policies for $\mathrm{K}-12$ education in Canada and beyond, the impact on higher education and advanced training, as well as avenues for future research in the field.
\end{abstract}

Keywords Academic integrity $\cdot$ Canada $\cdot$ Elementary school $\cdot$ Government $\cdot$ K-12 education $\cdot$ Policy implications $\cdot$ Secondary school

\author{
B. M. Stoesz ( $\bowtie)$ \\ University of Manitoba, Winnipeg, Canada \\ e-mail: Brenda.Stoesz@umanitoba.ca
}

S. E. Eaton and J. Christensen Hughes (eds.), Academic Integrity in Canada,

Ethics and Integrity in Educational Contexts 1,

https://doi.org/10.1007/978-3-030-83255-1_7 


\section{Understanding Provincial and Territorial Academic Integrity Policies for Elementary and Secondary Education in Canada}

When I began my career in education as a certified K-12 general science and biology teacher in the province of Manitoba, Canada approximately 20 years ago, I had many hopes, questions, and concerns about the best ways to facilitate student engagement in the learning process. I wondered how students' interests, home lives and responsibilities, extra-curricular activities, nutrition and health, and social-emotional well-being influenced their learning. Although I was concerned about test and exam cheating, I did not consult relevant school policies (not sure these even existed), and I was generally unfamiliar with the broader concept of academic integrity. Other K-12 teachers may feel similarly when guidance is lacking, and when there are so many other pressing issues to consider when teaching children and adolescents. Consequently, I may have encouraged behaviours that I would now describe as violations of academic integrity.

As I began to write this chapter, I recalled past discussions with my students about the skills required in university, including the importance of having some exposure to writing and documenting sources while in high school. Some students commented that they were planning to enrol in science courses so there was no need to learn how to cite properly. I explained that, as a science major, I completed many science courses (e.g., plant sciences, genetics) requiring writing and citing, so these skills were relevant across disciplines. Because my students claimed to have little or no experience with documenting their sources (see also Crossman, 2014), I designed science assignments that required writing, searching for appropriate sources, and acknowledging other authors' ideas. I provided feedback on strengths and mistakes and opportunities to correct errors. My goal was not to create experts, but to expose my students to some expectations that they would encounter during their postsecondary studies and potentially help them to avoid plagiarism. This chapter was borne, in part, from these early experiences as an educator.

\section{Background}

Information about various aspects of academic integrity and academic misconduct in higher education are readily available as research in this field has increased dramatically over the past several decades (Ali \& Aboelmaged, 2020). Cheating to gain an unfair advantage in academic work is a serious problem as it results in students who are less prepared for the next level in their education and are unable to apply knowledge and skills to workplace settings. Academic cheating is also linked to unethical workplace behaviour (Grimes, 2012; Lucas \& Friedrich, 2005; Nonis \& Swift, 2001). Because the consequences for engaging in academic misconduct can be detrimental to the individual and to society as a whole, many researchers, educators, 
and administrators in higher education are working to address the issue using a range of proactive and reactive approaches. A careful look at the academic integrity literature, however, exposes significant gaps in our understanding of academic integrity and misconduct in elementary and secondary education. One of those gaps relates to academic integrity policies. The goals of this chapter are to examine academic integrity in Canadian elementary and secondary education through a review of the literature and an examination of academic integrity policy at the provincial and territorial government level in Canada.

\section{Academic Misconduct in Elementary and Secondary Education}

Academic misconduct is not restricted to postsecondary education-students at every level are cheating (Davis et al., 2009) and the reported rates of academic cheating in K-12 levels may be increasing over time. The results from a survey conducted in the United States (US) revealed that 20\%, 27\%, and 30\% of students in 1969, 1979, and 1989, respectively, believed that most of their high school peers had engaged in academic cheating (Schab, 1991). Furthermore, 34\%, 60\%, and 68\% of high school students (during each of the three study periods) admitted to cheating on tests (Schab, 1991). In another US study, 93\% of high school students admitted to cheating at least once, with students in larger schools cheating more often than students in smaller schools (Galloway, 2012). High cheating rates were also found in a national survey of $>23,000$ high school students from across the US showing that $38 \%$ admitted to copying an internet document to submit as part of an assignment, 58\% admitted to cheating during tests, and $74 \%$ admitted to copying another student's homework (Josephson Institute Center for Youth Ethics, 2012). There is concern that "the problem of cheating is only increasing, that virtually nothing is being done currently about the problem (and students know that, too), and that students often lack explicit exposure to concepts related to academic integrity" (Cizek, 2003, p. 117).

American high school students are not the only ones making poor decisions regarding their schoolwork. When asked to reflect on their high school years, 58\% and $73 \%$ of first year university students in Canada admitted to cheating on tests and written work, respectively (Christensen Hughes \& McCabe, 2006). Similarly, $62 \%$ of students aged 12-18 years enrolled in private schools in Canada confessed to serious test cheating and $77 \%$ admitted to serious cheating in written work (Stoesz \& Los, 2019). Further, 6-17\% of junior high and high school students disclosed the turning in papers obtained from websites that did or did not charge fees (Stoesz \& Los, 2019). In both studies, a significant proportion of students admitted to working on assignments with others when their teachers asked for individual work and helping their peers cheat on tests. Students who had engaged in academic misconduct were also more likely to report that these behaviours were not serious (Christensen Hughes \& McCabe, 2006; Stoesz \& Los, 2019). 
When do cheating rates spike? High school students may be under the impression that cheating is a greater problem in high schools than it is in elementary schools or colleges (Schab, 1991). And there is some truth to this perception. Brandes (1986) explored the extent of cheating in 45 elementary schools $(n=1,037$ sixth graders) and 105 secondary schools ( $n=2,265$ mostly eleventh graders) in California. The rates of all types of cheating were higher amongst high school students than amongst sixth graders. About $39 \%$ and $41 \%$ of sixth graders admitted to cheating on tests and plagiarizing, respectively, whereas $74 \%$ and $50 \%$ of high school students disclosed engagement in those cheating behaviours (Brandes, 1986). Similarly, self-reported cheating on math tests and assignments increased after transition to a midwestern US state high school; cheating rates were stable during the eighth grade but then increased significantly from the beginning to the end of the ninth grade (Anderman \& Midgley, 2004). US high school students reported cheating on exams by looking at other students' exams or allowing others to view their exams more often than did college students (Jensen et al., 2002). In Canada, the trends appear similar in that the rates of academic misconduct in high schools are generally higher than the rates in post-secondary education (Christensen Hughes \& McCabe, 2006).

Why do high school students cheat? Although $99 \%$ of US high school students agreed that it was important for them "to be a person with good character" and 93\% indicated that their "parents/guardians always want [them] to do the ethically right thing, no matter what the cost", $36 \%$ of them feel that cheating may be necessary to succeed (Josephson Institute Center for Youth Ethics, 2012, pp. 4 \& 6). If high school students believe that doing the right thing is important, then why are so many of them choosing to cheat in their academic work?

There are several possible predictors for cheating during high school. Peer culture, achievement pressures, fear of failure (Schab, 1991), lack of consequences (Christensen Hughes \& McCabe, 2006), and failure to understand the actions that constitute plagiarism and other forms of academic misconduct are associated with increased rates of academic cheating in middle-school students (Wan \& Gut, 2008; Wan \& Scott, 2016). Parents may also facilitate the cheating behaviours of their children as they "have traditionally been encouraged by elementary and secondary schools to participate in their children's education" (Davis et al., 2009, p. 6). The COVID19 pandemic has only served to increase this pressure on parents to spend more time assisting their children with their schoolwork and supporting learning. Parent involvement in education is also viewed as caring for their children (Galloway \& Conner, 2015), but this caring may be misplaced in some circumstances. Some parents may not clearly understand the boundaries between helping their children and doing schoolwork for them and may inadvertently encourage behaviours that will later be viewed as inappropriate collaboration and contract cheating.

Increases in cheating from middle school to high school may also be attributed to changes in the goal structures of the learning environment, such that academic misconduct is more likely in classes with a perceived performance goal structure (emphasizing ability and competition) than mastery goal structure (emphasizing learning and effort) (Anderman \& Midgley, 2004; Murdock et al., 2004). Regardless of the goal structure of the learning environment, the likelihood of cheating 
increases when a teacher's pedagogy is perceived as poor (Murdock et al., 2004). Overwhelming quantities of content, grading on curves, having to complete just one or two assessments (Evans \& Craig, 1990; Galloway, 2012; Galloway \& Conner, 2015), and uncaring teachers (Curtis \& Clare, 2017; Murdock et al., 2004; Wangaard, 2016) increase the likelihood of cheating in middle school and high school. If teachers are perceived as uncaring, unfair, and discriminatory, "adolescents decide to cheat because" (Thorkildsen et al., 2007, p. 174) cheating is viewed "as a rational choice in a culture of warped values" (Kohn, 2007, p. xiv).

High school students also perceive that schools' academic integrity and misconduct policies lack clarity and are not enforced (Sisti, 2007; Stephens \& Wangaard, 2013), and they are "forced to cheat in a school culture that promotes getting ahead over learning" (Galloway, 2012, p. 378). When policies are absent or unclear, it should come as no surprise that students, parents, and teachers may all be confused about expectations for writing and plagiarism and collaboration to complete schoolwork, and the long-term and short-term consequences of engaging in academic misconduct. Therefore, clear, thoughtful, and detailed academic integrity policy provides a solid foundation for which to create cultures of integrity within schools at all levels of the education system (Bretag et al., 2011, 2014; Stephens \& Wangaard, 2013).

\section{The Canadian Context}

There is no federal ministry and no national oversight in Canadian education (see Bosetti et al., 2017; Capano, 2015; Eaton \& Christensen Hughes, 2022); education is decentralised to Canada's ten provinces and three territories. In six provinces and territories, single ministries of education are responsible for K-12 and postsecondary education, and separate ministries of education are responsible for K-12 and postsecondary education in seven provinces (see Table 7.1). Despite decentralization, there are similarities in the education systems across the country (Volante \& Ben Jaafar, 2008). For example, provincial and territorial governments have established partnerships to work toward common goals and align policies on curriculum design and assessment for primary and secondary education (see Capano, 2015). Historically, increased collaboration between provinces has been driven by reduced federal government funding especially during difficult economic times (Galway, 2012). Common education goals and financial constraints are argued to have fueled "a process of institutional isomorphism among provinces" (Capano, 2015, pp. 331332 ), but the alignment of goals and policies across the country may also communicate areas of priority for education leaders to the public. Partnerships across Canadian education systems might be expected to lead to further collaboration in areas such as academic integrity because of the closely related link to fair assessment and curriculum design.

Based on the research literature and my professional experiences as an educator and researcher, I formulated two questions about elementary and secondary education in Canada. Do ministries of education address academic integrity and misconduct 
Table 7.1 Academic integrity policy documents from provincial and territorial ministries of education

\begin{tabular}{|c|c|c|c|}
\hline $\begin{array}{l}\text { Province: Ministry of } \\
\text { Education Responsible for } \\
\text { K-12 Education }\end{array}$ & $\begin{array}{l}\text { Dedicated academic } \\
\text { integrity policy }\end{array}$ & Document Examined & Details \\
\hline $\begin{array}{l}\text { British Columbia (BC)**: } \\
\text { Ministry of Education }\end{array}$ & No & Not found & $\begin{array}{l}\text { Indication on website that } \\
\text { academic integrity policies } \\
\text { are created at lower district } \\
\text { or school levels. } \\
\text { Responsibility for } \\
\text { academic integrity is } \\
\text { placed on teachers and } \\
\text { students, in particular, } \\
\text { international students }\end{array}$ \\
\hline $\begin{array}{l}\text { Alberta }(\mathrm{AB})^{* *} \text { : Ministry } \\
\text { of Education }\end{array}$ & No & $\begin{array}{l}\text { The guiding framework } \\
\text { for the design and } \\
\text { development of } \\
\text { kindergarten to grade } 12 \\
\text { provincial curricula }\end{array}$ & $\begin{array}{l}\text { Does not address academic } \\
\text { integrity directly. Values } \\
\text { (i.e., fairness, } \\
\text { responsibility) deemed } \\
\text { important in education, } \\
\text { which overlap with the } \\
\text { academic integrity values }\end{array}$ \\
\hline $\begin{array}{l}\text { Saskatchewan }(\mathrm{SK})^{* *}: \\
\text { Ministry of Education }\end{array}$ & Yes & $\begin{array}{l}\text { Academic integrity and } \\
\text { student responsibility } \\
\text { guidelines }\end{array}$ & $\begin{array}{l}\text { Outlines school board, } \\
\text { in-school administrator, } \\
\text { teacher, and student, and } \\
\text { parent responsibility. } \\
\text { Template for model } \\
\text { academic integrity policy } \\
\text { at the division level } \\
\text { provided }\end{array}$ \\
\hline $\begin{array}{l}\text { Manitoba (MB)**: } \\
\text { Ministry of Education }\end{array}$ & & $\begin{array}{l}\text { Provincial assessment } \\
\text { Policy Kindergarten to } \\
\text { Grade 12: Academic } \\
\text { responsibility, honesty, } \\
\text { and promotion/retention }\end{array}$ & $\begin{array}{l}\text { Each division and school } \\
\text { must develop policies } \\
\text { aligned with government } \\
\text { policy }\end{array}$ \\
\hline $\begin{array}{l}\text { Ontario }(\mathrm{ON})^{* *} \text { : Ministry } \\
\text { of Education }\end{array}$ & No & $\begin{array}{l}\text { Ontario } \\
\text { schools-kindergarten to } \\
\text { grade } 12 \text { : Policy and } \\
\text { program requirements } \\
\text { Growing success: } \\
\text { Assessment, evaluation, } \\
\text { and reporting in Ontario } \\
\text { schools } 2010\end{array}$ & $\begin{array}{l}\text { Integrity is mentioned in } \\
\text { relation to the validity of } \\
\text { student's performance on a } \\
\text { test and } \\
\text { modification/adaptations } \\
\text { for students who } \\
\text { experience challenges }\end{array}$ \\
\hline $\begin{array}{l}\text { Quebec (PQ): Ministère de } \\
\text { l'Éducation et de } \\
\text { l'Enseignement supérieur* }\end{array}$ & No & $\begin{array}{l}\text { Policy on educational } \\
\text { success: A love of } \\
\text { learning, a chance to } \\
\text { succeed }\end{array}$ & $\begin{array}{l}\text { Ethics and religious } \\
\text { culture are curriculum } \\
\text { requirements. No mention } \\
\text { of academic integrity }\end{array}$ \\
\hline $\begin{array}{l}\text { New Brunswick (NB)**: } \\
\text { Department of Education } \\
\text { and Early Childhood } \\
\text { Development }\end{array}$ & No & $\begin{array}{l}\text { 10-year education plan: } \\
\text { Everyone at their best } \\
\text { (anglophone sector) }\end{array}$ & $\begin{array}{l}\text { No mention of integrity, } \\
\text { honesty, or other content } \\
\text { related to academic } \\
\text { integrity or academic } \\
\text { misconduct }\end{array}$ \\
\hline
\end{tabular}


Table 7.1 (continued)

\begin{tabular}{|c|c|c|c|}
\hline $\begin{array}{l}\text { Province: Ministry of } \\
\text { Education Responsible for } \\
\text { K-12 Education }\end{array}$ & $\begin{array}{l}\text { Dedicated academic } \\
\text { integrity policy }\end{array}$ & Document Examined & Details \\
\hline $\begin{array}{l}\text { Prince Edward Island } \\
(\mathrm{PEI})^{*} \text { : Department of } \\
\text { Education and Lifelong } \\
\text { Learning }\end{array}$ & No & Not found & \\
\hline $\begin{array}{l}\text { Nova Scotia (NS)**: } \\
\text { Department of Education } \\
\text { and early childhood } \\
\text { development }\end{array}$ & No & $\begin{array}{l}\text { Council to improve } \\
\text { classroom conditions (two } \\
\text { documents consisting of } \\
\text { meeting minutes } \\
\text { summarizing discussions) } \\
\text { Provincial school code of } \\
\text { conduct policy }\end{array}$ & $\begin{array}{l}\text { Meeting goal was to build } \\
\text { consensus on definition of } \\
\text { academic integrity (e.g., } \\
\text { plagiarism) Code of } \\
\text { conduct policy neglects } \\
\text { academic integrity and } \\
\text { academic misconduct }\end{array}$ \\
\hline $\begin{array}{l}\text { Newfoundland and } \\
\text { Labrador (NFLD)*: } \\
\text { Department of Education }\end{array}$ & Yes & $\begin{array}{l}\text { Assessment, evaluation } \\
\text { and reporting policy } \\
\text { (PROG-317) }\end{array}$ & $\begin{array}{l}\text { States that students "work } \\
\text { to the best of their abilities, } \\
\text { in an academically honest } \\
\text { manner and adhere to the } \\
\text { classroom/school Code of } \\
\text { Conduct" (p. 2). Short } \\
\text { section on academic } \\
\text { honesty for teachers, } \\
\text { students, parents, and } \\
\text { school administration. } \\
\text { Document is } \\
\text { non-academic misconduct } \\
\text { centric }\end{array}$ \\
\hline $\begin{array}{l}\text { Yukon }(\mathrm{YK}) * \text { : Department } \\
\text { of Education }\end{array}$ & No & & $\begin{array}{l}\text { Focus of government level } \\
\text { policies is on students' } \\
\text { physical safety/risk } \\
\text { management. Policies } \\
\text { related to fair assessment, } \\
\text { academic integrity, } \\
\text { misconduct (or academic } \\
\text { misconduct) were not } \\
\text { found }\end{array}$ \\
\hline $\begin{array}{l}\text { Northwest Territories } \\
(\mathrm{NWT})^{*} \text { : Department of } \\
\text { Education, Culture and } \\
\text { Employment }\end{array}$ & No & $\begin{array}{l}\text { Literacy with ICT Across } \\
\text { the Curriculum }\end{array}$ & $\begin{array}{l}\text { No policy on student } \\
\text { academic integrity or } \\
\text { academic misconduct, but } \\
\text { sparse details on } \\
\text { plagiarism, attribution, and } \\
\text { ethical use of information } \\
\text { within the IT literacy } \\
\text { curriculum }\end{array}$ \\
\hline
\end{tabular}


Table 7.1 (continued)

\begin{tabular}{l|l|l|l}
\hline $\begin{array}{l}\text { Province: Ministry of } \\
\text { Education Responsible for } \\
\text { K-12 Education }\end{array}$ & $\begin{array}{l}\text { Dedicated academic } \\
\text { integrity policy }\end{array}$ & Document Examined & Details \\
\hline $\begin{array}{l}\text { Nunavut (NU)*: } \\
\text { Department of Education }\end{array}$ & No & $\begin{array}{l}\text { Education Framework } \\
\text { Inuit Aaujimajatuqangit } \\
\text { for Nunavut Curriculum }\end{array}$ & $\begin{array}{l}\text { Not a stand-alone } \\
\text { academic integrity policy } \\
\text { document. This framework } \\
\text { document states that } \\
\text { integrity is important. No } \\
\text { details beyond this are } \\
\text { provided }\end{array}$ \\
\hline
\end{tabular}

Note *Denotes provinces and territories with single ministries of education responsible for both $\mathrm{K}-12$ and postsecondary education. **Denotes provinces with separate ministries of education for K-12 and for postsecondary education

through policy for elementary and secondary education? If these policies exist, what evidence demonstrates their influence on the implementation of academic integrity education at the school level? Academic integrity policy for K-12 education at the provincial and territorial level communicates the values that the community holds, provides a set of standards of quality, and guides the actions to uphold values and adhere to standards (Bretag \& Mahmud, 2016), and would provide an important foundation for further policy development at the school level.

\section{An Environmental Scan of Canadian Educational Policy for Academic Integrity}

To begin to examine these questions, I conducted an environmental scan of Canadian provincial and territorial ministry of education websites to identify academic integrity or academic misconduct policies. Environmental scans are used widely in private and government sectors (Rowel et al., 2005) to inform policy development, and planning and strategic decision-making processes (Charlton et al., 2019; Choo, 2002), and are associated with improved organizational performance (Choo, 2002). Environmental scans are also useful when there is uncertainty in the extent of the information available (Charlton et al., 2019) as it enables one to broaden the search for information beyond the organization or the peer-reviewed literature. For this chapter, government level academic integrity policy for K-12 education in Canada is absent from the research literature, thus environmental scanning was deemed appropriate for collecting information on this topic.

Environmental scanning often involves the collection of administrative data, internal reports, and guidelines using informants, observation, internet searches (Albright, 2004; Charlton et al., 2019), and information about external events, trends, and other influences (Choo, 2002) but "there are no prescribed standard methods. [for] information collection" (Rathi et al., 2017, p. 79). The environmental scan 
for this chapter took the simple form of internet searches of Canadian ministry of education websites. The search strategy included terms such as "academic integrity," "academic honesty," "academic misconduct", "plagiarism," and "attribution" in addition to the name of a province or territory and "education department" or "education ministry". Where these terms were not located in a broad search of the ministries' websites using Google's search function, webpages listing policies were scanned for titles with these terms and documents with titles related to fair assessment, information literacy, and student misconduct. The initial search was conducted in February 2020 and repeated in June 2020 to confirm the results of the initial search.

\section{Academic Integrity Policies at the Government Level}

My search revealed that few provincial and territorial ministries of education appear to provide any statements regarding student expectations for academic integrity, consequences for misconduct, and teacher and principal responsibilities for providing academic integrity education and responding to academic misconduct. Manitoba and Saskatchewan have each published stand-alone, publicly accessible, online academic integrity policy documents. The Manitoba Education policy outlines two fundamental values of academic integrity (i.e., honesty and responsibility) and lists the expectations of school divisions and schools (e.g., specify a range of consequences for academic misconduct and invoke sanctions), principals (e.g., respond appropriately to academic misconduct, report behaviour on report card), and teachers (e.g., clear communication of assignment expectations, support students' time management, communicate with parents) (Manitoba Education and Advanced Learning, 2015). There are two unique aspects of Saskatchewan's policy document: (a) the inclusion of a template for a model academic integrity policy at the school division/district level, and (b) a statement that "actions such as cheating; plagiarism; having others complete the work (e.g., parents/guardians); buying papers from the internet; or re-submission of previously submitted work are all examples of actions that are not in keeping with academic integrity" (Ministry of Education Government of Saskatchewan, 2011, p. 2). Although not a dedicated document for academic integrity, Newfoundland and Labrador published an assessment policy, which include statements about academic honesty and the responsibility of students, parents, teachers, and school administration regarding academic misconduct (Newfoundland \& Labrador English School District, 2013). This policy also emphasises the need for an educative approach and the importance of "second chance opportunities" when appropriate.

My environmental scan did not result in the identification of academic integrity or academic misconduct policies for any other region. This was somewhat surprising, particularly for the provinces of Ontario and Alberta as these provinces represent the most important cases of educational policy reforms, particularly in terms of the introduction of standardized assessments (Capano, 2015), which necessitates honesty, fairness, and trust in the processes and results of the evaluation in students' skills and abilities. Ontario's postsecondary sector is also extremely proactive in 
communicating the values of academic integrity by way of the Academic Integrity Council of Ontario (Ridgley et al., 2019), and similar networks are evolving in western Canadian provinces (McKenzie, 2018; Stoesz et al., 2020). The involvement of K-12 educators and administrators within these networks may facilitate a greater understanding of the importance of promoting academic integrity and in reducing academic misconduct in students' early education.

\section{Academic Integrity Policies at the Secondary School Level}

Next, I explored the extent to which government level academic integrity policy in Manitoba, Saskatchewan, and Newfoundland and Labrador may have impacted high school policy and practice. I randomly selected five high schools in each of Saskatchewan, Manitoba, and Newfoundland Labrador, and randomly selected five schools in each of three randomly-selected provinces that did not have a provincial level policy for academic integrity (i.e., British Columbia, Ontario, New Brunswick) using an online list randomizer (Random.Org, 2020). Next, I searched for academic integrity policies on the websites of the randomly selected high schools in each province from a publicly available list on each government's website. If the high school did not have a website, another school was randomly selected.

In Saskatchewan, only three of five high schools published academic integrity policies (within student handbooks) on their websites, which were limited in detail (e.g., few sentences, only described plagiarism). In Manitoba, two of five high schools had academic integrity statements, but details were also limited. Two of five high schools in Newfoundland and Labrador published academic integrity statements, and both referred to the government level policy. This appeared to communicate the message that academic integrity was important for stakeholders at all levels in the region's education system. Overall, only $47 \%$ of school handbooks examined referred to academic integrity policies. The selection of high schools and provinces for this set of analyses did not allow for the examination of the influence of the structure of ministries (i.e., ministries dedicated to K-12 education or those ministries that combined K-12 and higher education) on academic integrity policy development at the high school level. See Table 7.2.

Given the minimal information found on academic integrity policies in high schools, in those provinces that had government policies, I expected an even lower proportion of high schools to have academic integrity policies in those provinces without government-level policies. My hypothesis was not supported. Three, two, and three of the five high schools in British Columbia, Ontario, and New Brunswick (respectively) had academic integrity statements (overall 53\%). My inspection also revealed significantly more detail on non-academic misconduct and its consequences in high school policies, suggesting a greater need to deal with disruptive and dangerous behaviour because it often has immediate negative impacts on others within the learning environment (e.g., increased peer disciplinary problems, reduced 
Table 7.2 Academic integrity statements or policy documents from high schools in canada

\begin{tabular}{|c|c|c|}
\hline $\begin{array}{l}\text { Province School } \\
\text { District/Division, School }\end{array}$ & Student Handbook Examined & $\begin{array}{l}\text { Academic integrity statement or } \\
\text { policy (Yes/No). Details of policy, if } \\
\text { available }\end{array}$ \\
\hline \multicolumn{3}{|l|}{ Saskatchewan** } \\
\hline $\begin{array}{l}\text { Creighton SD 111, Creighton } \\
\text { Community School }\end{array}$ & Student Handbook (2019-2020) & $\begin{array}{l}\text { (Yes). Emphasis on plagiarism as an } \\
\text { act of fraud. More consequences for } \\
\text { late practices for assignments than } \\
\text { for plagiarism }\end{array}$ \\
\hline $\begin{array}{l}\text { Good Spirit SD 204, Yorkton } \\
\text { Regional High School }\end{array}$ & $\begin{array}{l}\text { Policies and Procedures for } \\
\text { Students and Parents: Academic } \\
\text { integrity and plagiarism }\end{array}$ & $\begin{array}{l}\text { (Yes). Teachers expected to use } \\
\text { technology and collaboration to } \\
\text { enhance teaching and learning. } \\
\text { Students expected to be honest, } \\
\text { complete coursework using their } \\
\text { own efforts, and not to copy or } \\
\text { plagiarize. Students may be } \\
\text { required to redo the assessment } \\
\text { honestly and/or attend an academic } \\
\text { integrity seminar }\end{array}$ \\
\hline $\begin{array}{l}\text { Horizon SD 205, Lanigan } \\
\text { Central High School }\end{array}$ & Not found & (No) \\
\hline $\begin{array}{l}\text { Saskatchewan Rivers SD } 119 \text {, } \\
\text { Carlton Comprehensive High } \\
\text { School }\end{array}$ & Not found & (No) \\
\hline $\begin{array}{l}\text { South East Cornerstone SD 209, } \\
\text { Estavan Comprehensive School }\end{array}$ & Student Handbook & $\begin{array}{l}\text { (Yes). Values statements (respect, } \\
\text { honesty) are provided. Plagiarism } \\
\text { and copyright infringement are } \\
\text { mentioned as well as inappropriate } \\
\text { access to materials (but this is not } \\
\text { about academic integrity). Final } \\
\text { exam policy does not address } \\
\text { academic misconduct, only exam } \\
\text { scheduling }\end{array}$ \\
\hline \multicolumn{3}{|l|}{ Manitoba** } \\
\hline $\begin{array}{l}\text { Beautiful Plains School } \\
\text { Division, Neepawa Area } \\
\text { Collegiate }\end{array}$ & N.A.C.I Policies & $\begin{array}{l}\text { (No). Examination policy describes } \\
\text { exemptions }\end{array}$ \\
\hline $\begin{array}{l}\text { Louis Riel School Division, } \\
\text { Glenlawn Collegiate }\end{array}$ & $\begin{array}{l}\text { Expectations for Students at } \\
\text { Glenlawn Collegiate }\end{array}$ & $\begin{array}{l}\text { (Yes). Emphasis on honesty and } \\
\text { fairness in the school division and } \\
\text { collegiate. Students expected to } \\
\text { meet accepted academic honesty } \\
\text { standards and consult teachers } \\
\text { about expectations. Consequences } \\
\text { for inappropriate collaboration, } \\
\text { plagiarism, and cheating }\end{array}$ \\
\hline $\begin{array}{l}\text { Mountain View School } \\
\text { Division, Gilbert Plains } \\
\text { Collegiate Institute }\end{array}$ & Code of Conduct & (No) \\
\hline
\end{tabular}


Table 7.2 (continued)

\begin{tabular}{|c|c|c|}
\hline $\begin{array}{l}\text { Province School } \\
\text { District/Division, School }\end{array}$ & Student Handbook Examined & $\begin{array}{l}\text { Academic integrity statement or } \\
\text { policy (Yes/No). Details of policy, if } \\
\text { available }\end{array}$ \\
\hline $\begin{array}{l}\text { River East Transcona School } \\
\text { Division, Collège Miles } \\
\text { MacDonell Collegiate }\end{array}$ & $\begin{array}{l}\text { Assessment Beliefs, Strategies and } \\
\text { Practices }\end{array}$ & $\begin{array}{l}\text { (Yes). Defines academic dishonesty } \\
\text { as "any submission of work that is } \\
\text { not wholly the student's such as } \\
\text { plagiarism, copying, cheating, not } \\
\text { citing sources" (para. 6). Teachers } \\
\text { determine if learning outcomes have } \\
\text { been legitimately met and assign a } \\
\text { "0" grade for compromised } \\
\text { assessments }\end{array}$ \\
\hline $\begin{array}{l}\text { Western School Division, } \\
\text { Morden Collegiate Institute } \\
\text { Collégial Morden }\end{array}$ & Code of Conduct & $\begin{array}{l}\text { (No). Single page devoted to } \\
\text { student conduct with nothing } \\
\text { further than general values } \\
\text { statements, but no specifics related } \\
\text { to academic integrity }\end{array}$ \\
\hline \multicolumn{3}{|l|}{ Newfoundland and Labrador* } \\
\hline $\begin{array}{l}\text { Avalon Region, Gonzaga High } \\
\text { School }\end{array}$ & Student Guidelines 2019-2020 & $\begin{array}{l}\text { (No). Nothing specific to academic } \\
\text { integrity }\end{array}$ \\
\hline $\begin{array}{l}\text { Avalon Region, Queen Elizabeth } \\
\text { Regional High School }\end{array}$ & 2019-2020 Student Handbook & $\begin{array}{l}\text { (Yes). Statements refer to the } \\
\text { provincial policies on academic } \\
\text { integrity }\end{array}$ \\
\hline $\begin{array}{l}\text { Central Region, J.M. Olds } \\
\text { Collegiate }\end{array}$ & Principles of Success & $\begin{array}{l}\text { (No). One statement on cheating: } \\
\text { "Cheating: Deliberately using } \\
\text { materials, information, or answers } \\
\text { on an exam/assignment that is not } \\
\text { your own" (p. 10) }\end{array}$ \\
\hline $\begin{array}{l}\text { Western Region, Indian River } \\
\text { High School }\end{array}$ & $\begin{array}{l}\text { Assessment, Evaluation and } \\
\text { Reporting Policy Guidelines }\end{array}$ & $\begin{array}{l}\text { (No). No specific details about } \\
\text { academic integrity. Policy statement } \\
\text { relates to late assignment } \\
\text { submission }\end{array}$ \\
\hline $\begin{array}{l}\text { Labrador Region, Mealy } \\
\text { Mountain }\end{array}$ & $\begin{array}{l}\text { Assessment and Evaluation } \\
\text { Guidelines (2018-2019) }\end{array}$ & $\begin{array}{l}\text { (Yes). One-page outline of the } \\
\text { expectations for students and } \\
\text { teachers, and administration along } \\
\text { with consequences. Details are } \\
\text { limited }\end{array}$ \\
\hline \multicolumn{3}{|l|}{ British Columbia** } \\
\hline $\begin{array}{l}\text { District } 19, \text { Revelstoke } \\
\text { Secondary }\end{array}$ & $\begin{array}{l}\text { Code of Conduct, Student } \\
\text { Handbook, Athletic Handbook }\end{array}$ & $\begin{array}{l}\text { (Yes). Academic misconduct is } \\
\text { deemed an example of a behaviour } \\
\text { that is moderately inappropriate. } \\
\text { One statement about plagiarism }\end{array}$ \\
\hline $\begin{array}{l}\text { District } 37 \text {, South Delta } \\
\text { Secondary }\end{array}$ & Handbook/ Conduct & $\begin{array}{l}\text { (Yes). Statement of academic } \\
\text { integrity with a focus on plagiarism } \\
\text { and cheating. Several examples are } \\
\text { provided and a statement of the } \\
\text { importance of integrity for school } \\
\text { and personal reputation }\end{array}$ \\
\hline
\end{tabular}


Table 7.2 (continued)

\begin{tabular}{|c|c|c|}
\hline $\begin{array}{l}\text { Province School } \\
\text { District/Division, School }\end{array}$ & Student Handbook Examined & $\begin{array}{l}\text { Academic integrity statement or } \\
\text { policy (Yes/No). Details of policy, if } \\
\text { available }\end{array}$ \\
\hline $\begin{array}{l}\text { District } 51 \text {, Grand Forks } \\
\text { Secondary }\end{array}$ & GFSS Student Code of Conduct & (No) \\
\hline District 58, Merritt Secondary & Merritt Secondary Code of Conduct & (No) \\
\hline District 33, Sardis Secondary & 2019-2020 Student Planner & $\begin{array}{l}\text { (Yes). At least a page of information } \\
\text { on plagiarism and cheating; } \\
\text { consequences are limited }\end{array}$ \\
\hline \multicolumn{3}{|l|}{ Ontario** } \\
\hline F E Madill Secondary School & $\begin{array}{l}\text { Handbook/Code of Conduct } \\
\text { Assessment Policy }\end{array}$ & $\begin{array}{l}\text { (Yes). Some definitions, education, } \\
\text { consequences included in the } \\
\text { Assessment Policy }\end{array}$ \\
\hline Sudbury Secondary School & Student Handbook & $\begin{array}{l}\text { (Yes). Plagiarism is listed as an } \\
\text { infraction and is defined. Distinct } \\
\text { documentation styles are mentioned } \\
\text { because of the expected use at } \\
\text { postsecondary institutions. The } \\
\text { approach to consequences for } \\
\text { plagiarism are different for grades } \\
9-10 \text { and } 11-12 \text { and is partly } \\
\text { dependent on intentionality of the } \\
\text { offence }\end{array}$ \\
\hline $\begin{array}{l}\text { District School Board of Niagara } \\
\text { (DSBN), Stamford Collegiate }\end{array}$ & DSBN Code of Conduct & $\begin{array}{l}\text { (No). Simply states that integrity is } \\
\text { important }\end{array}$ \\
\hline Westmount Secondary School & $\begin{array}{l}\text { Ownership and Authorship } \\
\text { Procedure }\end{array}$ & $\begin{array}{l}\text { (No). Detailed procedure about } \\
\text { ownership, authorship, for all } \\
\text { members of the learning community }\end{array}$ \\
\hline $\begin{array}{l}\text { Lakehead Public Schools, } \\
\text { Hammarskjold High School }\end{array}$ & Not found & $\begin{array}{l}\text { (No). Details non-academic } \\
\text { misconduct }\end{array}$ \\
\hline \multicolumn{3}{|l|}{ New Brunswick** } \\
\hline A-East, Caledonia Regional & Student Handbook 2019-2020 & $\begin{array}{l}\text { (Yes). Plagiarism and cheating with } \\
\text { consequences of re-doing the } \\
\text { assignment or exam }\end{array}$ \\
\hline $\begin{array}{l}\text { A-South, St. Malachy's } \\
\text { Memorial High School }\end{array}$ & Not found & (No) \\
\hline $\begin{array}{l}\text { A-North, Miramichi Valley } \\
\text { High School }\end{array}$ & Student Handbook 2019-2020 & $\begin{array}{l}\text { (Yes). "Plagiarism is illegal." } \\
\text { Provide tips on avoiding plagiarism } \\
\text { and what plagiarism is. Second on } \\
\text { cheating, and consequences }\end{array}$ \\
\hline $\begin{array}{l}\text { A-West, Central New } \\
\text { Brunswick Academy }\end{array}$ & Student Handbook 2018-2019 & (No) \\
\hline Fredericton High & Student Handbook 2019-2020 & $\begin{array}{l}\text { (Yes). Plagiarism policy with } \\
\text { definitions, details, and } \\
\text { consequences; personal electronic } \\
\text { devices in terms of cheating }\end{array}$ \\
\hline
\end{tabular}

Note *Denotes provinces and territories with single ministries of education responsible for both $\mathrm{K}-12$ and postsecondary education. **Denotes provinces with separate ministries of education for K-12 and for postsecondary education 
peer test scores; Figlio, 2007). Unfortunately, even behaviour policies and the implementation of them are often described as ambiguous, superficial, and ineffective (Rowe, 2006).

The lack of policies and/or the inconsistent approaches to academic integrity education in K-12 education in Canada suggests several issues that require further investigation. First, structural changes that have occurred in education in an effort to increase efficiencies (Capano, 2015), including an overall shift in accountability such that schools have greater autonomy and locally elected school boards have reduced authority (Galway, 2012), may result in a communication gap between government level decisions and adoption of policy at the school level. Second, elected leaders may not have prioritized honesty, trustworthiness, and responsibility in student learning and assessment or in the education system as a whole, resulting in an inconsistency in the adoption of the values of academic integrity at the school level, potentially leading to a general apathy among students, parents, and teachers. The efforts of my colleagues and I to discuss academic integrity with high school educators have often been met with defensiveness, denial, and statements that academic integrity is not applicable to high school students because they are "just becoming scholars." My experiences are consistent with research demonstrating that teachers often underestimate or reject the idea that cheating is occurring in their classes, even when they admit that cheating is a significant problem in middle and high schools (Evans \& Craig, 1990). Perhaps denial stems from teachers' lack of training and tools to promote academic integrity or deal with academic misconduct effectively.

Deprioritizing academic integrity education may have long-term implications for primary and secondary students, particularly as they transition to their postsecondary studies. Students are often expected to make a huge leap in understanding the rules and overall academic culture as they transition from high school to postsecondary and professors believe that students should have mastered skills, such as writing and citing, prior to their arrival at university (Peters \& Cadieux, 2019). Students also perceive that postsecondary faculty take academic integrity and misconduct more seriously and implement strategies to discourage cheating more often than did their high school teachers (Christensen Hughes \& McCabe, 2006). Thus, the enormous mismatch between the expectations for acting with integrity across educational levels is problematic and disadvantages students as they begin postsecondary studies. Although the majority of policies at the postsecondary level for academic integrity are imperfect and lack the level of detail (McKenzie et al., 2020; Stoesz et al., 2019; Stoesz \& Eaton, 2020) recommended by leading academic integrity policy experts (Bretag et al., 2011), the contrast between K-12 and postsecondary policy for academic integrity in Canada is mindboggling.

\section{Implications for K-12 Classrooms in Canada}

As part of the development or revision of academic integrity policies, careful examination of how assessment policies and programs influence academic integrity or fuel 
academic cheating is essential. In Canadian K-12 education systems, high stakes assessments of provincial and territorial assessment programs have important consequences for secondary students-in some jurisdictions results from these assessments make up 30-50\% of final grades and/or serve as graduation requirements (Volante \& Ben Jaafar, 2008). Research data in the US suggests that high stakes exams contribute to academic misconduct by students in both K-12 education and postsecondary studies (Nichols \& Berliner, 2007). Although provincial standardized assessments have been implemented to legitimize Canadian education on the global stage, improve teaching and learning systems, and to hold educators accountable (see Volante \& Ben Jaafar, 2008), there has been substantial debate over the value of these assessments to serve these purposes (Cizek, 2001). Moreover, the link between high stakes standardized assessment and the pressure to cheat needs to be examined closely within the Canadian K-12 education context. Success in K-12 has traditionally been measured by achievement of high test scores, acceptance to postsecondary studies, and numerous accomplishments-when these are valued above the quality of learning, students may feel enormous pressure, and cheating may be seen as one way to both achieve and to alleviate the pressure (Galloway, 2012). Thus, exploring the association between standardized assessment and cheating may require that the definitions of success for elementary and secondary school students need to be reimagined (Galloway, 2012).

Changing current practice would arguably be enhanced if teacher training programs in postsecondary institutions were to provide preservice teachers with holistic education on academic integrity, including an understanding of the various perspectives and cultural traditions (e.g., First Nations perspectives; Lindstrom, 2022; Poitras Pratt \& Gladue, 2022), and ethical assessment in K-12 education (Malone, 2020; Sisti, 2007; Wan \& Scott, 2016). Such education would help to ensure that they are equipped to make professional decisions and can model the values of honesty, respect, and responsibility upon entry into the profession. This is necessary as teachers serve as important role models and are held to high standards in terms of their character and values (Lumpkin, 2008). Administrators in elementary and secondary schools should also ensure that teachers feel comfortable discussing school procedures with them (Yoannou, 2014) and have access to ongoing professional development to stay current with the latest developments in the field of academic integrity (Wan \& Scott, 2016). Teachers who value, model, and practice academic integrity are more likely to provide direct instruction to students so that they can develop the appropriate skills to complete their assignments with integrity (Peters \& Cadieux, 2019).

Teachers also need guidance from good policy and be prepared with the skills required to deal with cheating promptly, consistently, and effectively when it is identified (Davis et al., 2009). Effective intervention is possible only when the circumstances surrounding the cheating situation are understood. For example, if students have not been instructed or have not had time to practice learning with integrity, behaviours could be viewed as "teachable moments" for building skills rather than executing a standardized punishment (McGowan, 2005; Wan \& Scott, 2016). Moreover, because of the increasing rates of academic misconduct at the high school 
level, teaching relevant skills in the early elementary grades is necessary. Relevant education may be provided through the digital and information literacy curricula, however, the message that academic integrity is important in all schoolwork would be stronger if academic integrity education was woven throughout all core subject areas (Lampert, 2008). Finally, parents can support efforts to promote integrity "by talking to their children about the valuing of learning and honesty over grades, by tempering their own desire for their children to succeed at all costs, and by supporting the teacher in disciplining their children when they are caught cheating" (Davis et al., 2009, pp. 65-66).

\section{Conclusion}

My environmental scan revealed that few provincial and territorial ministries of education provided guidance to students on academic integrity and consequences for misconduct, or teacher and administrator responsibilities for providing academic integrity education and responding to academic misconduct. Interestingly, an association between the presence or absence of government and school level policies was not evident. Education leaders at the provincial, school division, and school levels in Canada should work together to develop holistic policies that are informed by research and the experiences of all stakeholders, including educators, parents, and students. Such policies must support teaching and learning environments where academic integrity is deemed valuable, is highly respected, and is consistently practiced, and that fosters the development of trusting relationships between students and teachers to support learning (Wan \& Scott, 2016). Academic integrity policies must also provide guidance for appropriate consequences for academic misconduct, while at the same time avoiding the development of " ... a climate of fear among students and a desire to challenge the system" (Bailey, 2010) by implementing zero tolerance policies, which may be flawed and ineffective (e.g., as shown for non-academic misconduct; Martinez, 2009). Policies must emphasize the values of academic integrity (International Center for Academic Integrity (ICAI), 2021), the importance of proper attribution, and strengthening information literacy skills (Wan $\&$ Scott, 2016), so that students in elementary and secondary education are not simply avoiding punishment but moving towards learning with integrity. Finally, postsecondary institutions must provide preservice K-12 teachers with holistic education on academic integrity, including various ways it is understood and expressed based on cultural traditions (e.g., Lindstrom, 2022; Poitras Pratt \& Gladue, 2022) and ethical assessment (Malone, 2020; Sisti, 2007; Wan \& Scott, 2016). 


\section{References}

Albright, K. (2004). Environmental scanning: Radar for success. Information Management, 38(3), 38.

Ali, I., \& Aboelmaged, M. (2020). A bibliometric analysis of academic misconduct research in higher education: Current status and future research opportunities. Accountability in Research, O0(00), 1-22. https://doi.org/10.1080/08989621.2020.1836620

Anderman, E. M., \& Midgley, C. (2004). Changes in self-reported academic cheating across the transition from middle school to high school. Contemporary Educational Psychology, 29(4), 499-517. https://doi.org/10.1016/j.cedpsych.2004.02.002

Bailey, J. (2010). How schools are hurting the fight against plagiarism. Plagiarism Today. https:// www.plagiarismtoday.com/2010/05/10/how-schools-are-hurting-the-fight-against-plagiarism/

Bosetti, L., Van Pelt, D., \& Allison, D. (2017). The changing landscape of school choice in Canada: From pluralism to parental preference? Education Policy Analysis Archives, 25, 38. https://doi. org/10.14507/epaa.25.2685

Brandes, B. (1986). Academic honesty: A special study of California students. https://eric.ed.gov/? id=ED272533

Bretag, T., Mahmud, S., Wallace, M., Walker, R., McGowan, U., East, J., Green, M., Partridge, L., \& James, C. (2014). Teach us how to do it properly! An Australian academic integrity student survey. Studies in Higher Education, 39(7), 1150-1169. https://doi.org/10.1080/03075079.2013. 777406

Bretag, T., \& Mahmud, S. (2016). A conceptual framework for implementing exemplary academic integrity policy in Australian higher education. In Handbook of Academic Integrity (pp. 463-480). https://doi.org/10.1007/978-981-287-098-8

Bretag, T., Mahmud, S., Wallace, M., Walker, R., James, C., Green, M., East, J., Mcgowan, U., \& Partridge, L. (2011). Core elements of exemplary academic integrity policy in Australian higher education. International Journal for Educational Integrity, 7(2), 3-12. http://www.ojs.unisa.edu. au/journals/index.php/IJEI/

Capano, G. (2015). Federal dynamics of changing governance arrangements in education: A comparative perspective on Australia, Canada and Germany. Journal of Comparative Policy Analysis: Research and Practice, 17(4), 322-341. https://doi.org/10.1080/13876988.2014.952530

Charlton, P., Doucet, S., Azar, R., Nagel, D. A., Boulos, L., Luke, A., Mears, K., Kelly, K. J., \& Montelpare, W. J. (2019). The use of the environmental scan in health services delivery research: A scoping review protocol. BMJ Open, 9(9). https://doi.org/10.1136/bmjopen-2019-029805

Choo, C. W. (2002). Environmental scanning as information seeking and environmental scanning as information seeking and organizational knowing. PrimaVera, 2(1), 2002.

Christensen Hughes, J. M., \& McCabe, D. (2006). Academic misconduct within higher education in Canada. Canadian Journal of Higher Education, 36(2), 1-21.

Cizek, G. J. (2001). More unintended consequences of high-stakes testing. Educational Measurement: Issues and Practice, 20(4), 19-27. https://doi.org/10.1111/j.1745-3992.2001.tb00072.x

Cizek, G. J. (2003). Detecting and preventing classroom cheating: Promoting integrity in assessment (Vol. 3). Corwin Press, Inc.

Crossman, K. E. (2014). Intensive English for academic purposes: A curriculum designed and developed for local English language learners entering university. https://doi.org/10.11575/PRISM/ 26594

Curtis, G. J., \& Clare, J. (2017). How prevalent is contract cheating and to what extent are students repeat offenders? Journal of Academic Ethics, 15(2), 115-124. https://doi.org/10.1007/s10805017-9278-x 
Davis, S. F., Drinan, P. F., \& Bertram Gallant, T. (2009). Cheating in school: What we know and what we can do. Wiley-Blackwell. https://doi.org/10.1080/00098655.1966.11477001

Eaton, S. E., \& Christensen Hughes, J. M. C. (2022). Academic integrity in Canada: Historical perspectives and current trends. In Academic Integrity in Canada. Springer.

Evans, E. D., \& Craig, D. (1990). Teacher and student perceptions of academic cheating in middle and senior high schools. The Journal of Educational Research, 84(1), 44-53. https://doi.org/10. 1080/00220671.1990.10885989

Figlio, D. N. (2007). Boys named Sue: Disruptive children and their peers. Education Finance and Policy, 2(4), 376-394. https://doi.org/10.1162/edfp.2007.2.4.376

Galloway, M. K. (2012). Cheating in advantaged high schools: Prevalence, justifications, and possibilities for change. Ethics and Behavior, 22(5), 378-399. https://doi.org/10.1080/10508422.2012. 679143

Galloway, M. K., \& Conner, J. (2015). Perpetuating privilege: Students' perspectives on the culture of a high-performing and high-pressure high school. The Educational Forum, 79(2), 99-115. https://doi.org/10.1080/00131725.2014.1002592

Galway, G. (2012). Lessons in leadership: Perspectives on corporate managerialism and educational reform. Canadian Journal of Educational Administration and Policy, 130, 32. https://www.uma nitoba.ca/publications/cjeap/pdf_files/galway.pdf

Grimes, P. W. (2012). Dishonesty Business: In Academics A Cross-Cultural and Evaluation of Student Attitudes, 49(3), 273-290.

International Center for Academic Integrity (ICAI). (2021). The fundamental values of academic integrity (3rd ed.). www.academicintegrity.org/the-fundamental-valuesof-academic-integrity

Jensen, L. A., Arnett, J. J., Feldman, S. S., \& Cauffman, E. (2002). It's wrong, but everybody does it: Academic dishonesty among high school and college students. Contemporary Educational Psychology, 27(2), 209-228. https://doi.org/10.1006/ceps.2001.1088

Josephson Institute Center for Youth Ethics. (2012). 2012 report card on the ethics of American youth—honesty. http://charactercounts.org/programs/reportcard/2012/installment_reportcard_honesty-integrity.html

Kohn, A. (2007). Foreword. In E. M. Anderman \& T. B. Murdock (Eds.), Psychology of academic cheating (pp. 11-19). Amsterdam: Elsevier.

Lampert, L. D. (2008). Student academic integrity. In Information Literacy Instruction Handbook (pp. 149-163). American Library Association. http://hdl.handle.net/10211.2/1998

Lindstrom, G. (2022). Accountability, relationality and Indigenous epistemology: Advancing an Indigenous perspective on academic integrity. In S. E. Eaton \& J. Christensen Hughes (Eds.), Academic Integrity in Canada. Springer.

Lucas, G. M., \& Friedrich, J. (2005). Individual differences in workplace deviance and integrity as predictors of academic dishonesty. Ethics \& Behavior, 15(1), 15-35. https://doi.org/10.1207/s15 327019eb1501_2

Lumpkin, A. (2008). Teachers as role models teaching character and moral virtues. Journal of Physical Education, Recreation \& Dance, 79(2), 45-50. https://doi.org/10.1080/07303084.2008. 10598134

Malone, D. M. (2020). Ethics education in teacher preparation: A case for stakeholder responsibility. Ethics and Education, 15(1), 77-97. https://doi.org/10.1080/17449642.2019.1700447

Manitoba Education and Advanced Learning. (2015). Provincial assessment policy kindergarten to grade 12: Academic responsibility, honesty, and promotion/retention. https://www.edu.gov.mb. $\mathrm{ca} / \mathrm{k} 12 /$ assess/publications.html 
Martinez, S. (2009). A system gone berserk: How are zero-tolerance policies really affecting schools? Preventing School Failure: Alternative Education for Children and Youth, 53(3), 153-158. https://doi.org/10.3200/psfl.53.3.153-158

McGowan, U. (2005). Academic integrity: An awareness and development issue for students and staff. Journal of University Teaching and Learning Practice, 2(3), 48-57. http://ro.uow.edu.au/ jutlp/vol2/iss $3 / 6$

McKenzie, A. M., Miron, J. B., Eaton, S. E., Persaud, N., Steeves, M., Stoesz, B. M., \& Thacker, E. (2020). Contract cheating language within academic integrity policies in the university sector in Ontario. In International Center for Academic Integrity 2020 Conference. Canada.

McKenzie, A. M. (2018). Academic integrity across the Canadian landscape. Canadian Perspectives on Academic Integrity, 1(2), 40-45. https://doi.org/10.11575/CPAI.V1I2.54599.G42964

Ministry of Education Government of Saskatchewan. (2011). Academic integrity and student responsibility guidelines.

Murdock, T. B., Miller, A., \& Kohlhardt, J. (2004). Effects of classroom context variables on high school students' judgments of the acceptability and likelihood of cheating. Journal of Educational Psychology, 96(4), 765-777. https://doi.org/10.1037/0022-0663.96.4.765

Newfoundland \& Labrador English School District. (2013). Assessment, Evaluation and Reporting (PROG-317).

Nichols, S. L., \& Berliner, D. C. (2007). The pressure to cheat in a high-stakes testing environment. In Psychology of academic cheating (pp. 289-311). Elsevier Inc. https://doi.org/10.1016/B978012372541-7/50016-4.

Nonis, S., \& Swift, C. O. (2001). An examination of the relationship between academic dishonesty and workplace dishonesty: A multicampus investigation. Journal of Education for Business, 77(2), 69-77. https://doi.org/10.1080/08832320109599052

Peters, M., \& Cadieux, A. (2019). Are Canadian professors teaching the skills and knowledge students need to prevent plagiarism? International Journal for Educational Integrity, 15(1), 1-16. https://doi.org/10.1007/s40979-019-0047-z

Poitras Pratt, Y., \& Gladue, K. (2022). Re-defining academic integrity: Embracing Indigenous truths. In S. E. Eaton \& J Christensen Hughes (Eds.), Academic Integrity in Canada. Springer.

Random.Org. (2020). List randomizer. Random.Org. https://www.random.org/lists/

Rathi, D., Shiri, A., \& Cockney, C. (2017). Environmental scan: A methodological framework to initiate digital library development for communities in Canada's North. Aslib Journal of Information Management, 69(1), 76-94. https://doi.org/10.1108/AJIM-06-2016-0082

Ridgley, A., Miron, J. B., \& McKenzie, A. (2019). Building a regional academic integrity network: Profiling the growth and action of the Academic Integrity Council of Ontario. Paper presented at the Canadian Symposium on Academic Integrity, Calgary, Canada. http://hdl.handle.net/1880/ 110308

Rowe, D. (2006). Taking responsibility: School behaviour policies in England, moral development and implications for citizenship education. Journal of Moral Education, 35(4), 519-531. https:// doi.org/10.1080/03057240601026865

Rowel, R., Moore, N. D., Nowrojee, S., Memiah, P., \& Bronner, Y. (2005). The utility of the environmental scan for public health practice: Lessons from an urban program to increase cancer screening. Journal of the National Medical Association, 97(4), 527-534.

Schab, F. (1991). Schooling without learning: Thirty years of cheating in high school. Adolescence, 26, 839-847. 
Sisti, D. A. (2007). How do high school students justify internet plagiarism? Ethics \& Behavior, 17(3), 215-231. https://doi.org/10.1080/10508420701519163

Stephens, J. M., \& Wangaard, D. B. (2013). Using the epidemic of academic dishonesty as an opportunity for character education: A three-year mixed methods study (with mixed results). Peabody Journal of Education, 88(2), 159-179. https://doi.org/10.1080/0161956X.2013.775868

Stoesz, B. M., \& Eaton, S. E. (2020). Academic integrity policies of publicly funded universities in western Canada. Educational Policy. https://doi.org/10.1177/0895904820983032

Stoesz, B. M., Eaton, S. E., Miron, J., \& Thacker, E. J. (2019). Academic integrity and contract cheating policy analysis of colleges in Ontario Canada. International Journal for Educational Integrity, 15(1), 1-18. https://doi.org/10.1007/s40979-019-0042-4

Stoesz, B. M., \& Los, R. (2019). Evaluation of a tutorial designed to promote academic integrity. Canadian Perspectives on Academic Integrity, 2(1), 3-26. https://doi.org/10.11575/cpai.v2i1

Stoesz, B. M., Gervais, L., Usick, B., Seeland, J., MacLeod, P., Vogt, L., Markovics, L., \& Denham, T. (2020). Creating a collaborative network to promote cultures of academic integrity in Manitoba's postsecondary institutions [Practioner article]. Canadian Perspectives on Academic Integrity, 3, 39-48. https://doi.org/10.11575/cpai.v3i1.69763

Thorkildsen, T. A., Golant, C. J., \& Richesin, L. D. (2007). Reaping what we sow: Cheating as a mechanism of moral engagement. In E. M. Anderman \& T. B. Murdock (Eds.), Psychology of academic cheating (pp. 171-202). Elsevier. https://doi.org/10.1016/B978-012372541-7/50012-7

Volante, L., \& Ben Jaafar, S. (2008). Educational assessment in Canada. Assessment in Education: Principles, Policy and Practice, 15(2), 201-210. https://doi.org/10.1080/09695940802164226

Wan, G., \& Gut, D. (2008). Roles of media and media literacy education: Lives of Chinese and American adolescents. New Horizons in Education, 56(2), 28-42. http://www.ln.edu.hk/osl/new horizon/abstract/v56n2/3.pdf

Wan, G., \& Scott, M. R. (2016). Start them early and right: Creating a culture of academic integrity in elementary schools. In T. Bretag (Ed.), Handbook of Academic Integrity (pp. 413-427). Singapore: Springer.

Wangaard, D. B. (2016). Practices to support developing academic integrity in secondary school students. In T. Bretag (Ed.), Handbook of Academic Integrity (pp. 429-448). Springer:Singapore. https://doi.org/10.1007/978-981-287-098-8_34

Yoannou, A. (2014). Academic integrity: Perceptions and practices in secondary school humanities classes. University of Toronto.

Brenda M. Stoesz In her role as a Senior Faculty Specialist (Academic Integrity Initiative), Dr. Brenda M. Stoesz provides support for instructors through the development and facilitation of workshops and other resources related to innovations in teaching and learning in higher education, most notably in the area of academic integrity. Stoesz also applies research and evaluation methods from various fields to examine holistic aspects of teaching and learning in higher education, including academic integrity broadly, contract cheating, and the perception and use of online learning environments. 
Open Access This chapter is licensed under the terms of the Creative Commons Attribution 4.0 International License (http://creativecommons.org/licenses/by/4.0/), which permits use, sharing, adaptation, distribution and reproduction in any medium or format, as long as you give appropriate credit to the original author(s) and the source, provide a link to the Creative Commons license and indicate if changes were made.

The images or other third party material in this chapter are included in the chapter's Creative Commons license, unless indicated otherwise in a credit line to the material. If material is not included in the chapter's Creative Commons license and your intended use is not permitted by statutory regulation or exceeds the permitted use, you will need to obtain permission directly from the copyright holder.

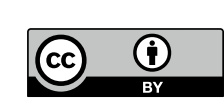

